\title{
IAMJ
}

INTERNATIONAL

AYURVEDIC

MEDICAL JOURNAL

\section{POTENTIAL OF AYURVEDIC TREATMENT MODALITIES IN RADIATION INDUCED DERMATITIS}

\author{
Sonawane Vrushali ${ }^{1}$, Narode Sagar $^{2}$ \\ ${ }^{1}$ PG Scholar, ${ }^{2}$ Associate Professor, \\ Agad Tantra Avum Vidhi Vaidyak Shree Saptashrungi Ayurved Mahavidyalaya, Nashik, Maharashtra, India \\ Email: dr.vrushalinp@gmail.com
}

https://doi.org/10.46607/iamj0807222020

(Published online: July 2020)

Open Access

(C) International Ayurvedic Medical Journal, India 2020

Article Received: 29/06/2020 - Peer Reviewed: 09/07/2020 - Accepted for Publication: 11/07/2020

Check for updates

\begin{abstract}
Cancer has become one of the leading cause of deaths. The conventional treatment modalities in treating cancer includes Surgery, Chemotherapy, Radiation and Immuno therapy. Amongst this, radiation therapy is one of the frequently used treatment modality. $95 \%$ of cancer patients receiving radiation therapy will develop some form of radiodermatitis, including erythema, dry\& moist desquamation, ulcerations, necrosis etc. This kind of reactions may lead to delay in the treatment, affects the quality of life, diminishes the cosmesis and causes functional deficits. Despite the prevalence of radiation dermatitis, there is no gold standard in the prevention and management of this condition. Ayurvedic treatment modalities has the potential in reducing the dermatological effects. Local treatment modalities like Lepa, Pichu, Parishek, Rasayanas, lifestyle management may help in ameliorating the dermatological effects. This article includes radiation induced dermatitis its stages its clinical manifestation and role of Ayurveda in managing it.
\end{abstract}

Keywords: Dermatitis, Rasayanas, Dushivishari Agad

\section{INTRODUCTION}

Radiotherapy is an essential component in the management of cancer patients and is used either alone or in combination with surgery or chemotherapy. In 2016, there were an estimated 3.05 million cancer survivors treated with radiation, accounting for $29 \%$ of all cancer survivors. The number of radiationtreated cancer survivors is projected to reach 3.38 million by 2020 and 4.17 million by $2030^{1}$ of those receiving RT, as many as $95 \%$ may experience some form of radiation dermatitis, or radiation-induced 
skin injury ${ }^{2}$ Severity of symptoms depends on intrinsic factors like age, general health, ethnic origin, hormonal status, genetic predisposition, basal skin conditions, co morbidities, pre-existing connective tissue and/or autoimmune disorders, and skin phototype; while extrinsic factors like radiation dose, volume, and number of fractions of radiation play a role. Dermatitis is associated with pain, warmth, burning, and itching, and may impair quality of life and the treatment schedule, thereby possibly being prejudicial to the effective local control of the tumor cells. $^{3}$

Despite the technological advances, there is no gold standard in management of radiation dermatitis. Ayurvedic treatment modalities have potential in reducing the radiation induced dermatitis. Treatment modalities in the form of local treatment - Lepa, Pichu, Parishek, systemic treatments like $R a$ sayanas, dietary modifications, may help in ameliorating the toxic dermatological effects.

In Ayurveda, Agadatantra is one amongst the ashtanga which deals with toxicology.

According to Sushruta samhita, Dushivisha (cumulative poison); is a form of toxin (animal

origin, plant origin, artificial poison) that has not been eliminated or neutralized due to various reasons, remains in the body for some time and eventually gets manifested in the form of some disease. Premonitory symptoms of Dushivisha has many skin manifestations like Mandala, Kotha, Kushtha.

In Ayurveda many skin diseases are mentioned under Kshudrakushtha and Mahakushtha. The three vitiated dosas viz Vayu, Pitta and Kapha, in turn vitiate the Tvak, Rakta, Mamsa And Lasika These taken together, constitute the seven-fold pathogenic substance of Kushtha. ${ }^{4}$

\section{Aim:}

1) To understand the pathophysiology of Radiation induced dermatitis

2) To study different ayurvedic modalities in overcoming the ill effects caused due to radiation.

\section{Methods:}

1) To study the available literature about Radiation dermatitis

2) Ayurvedic treatment modalities for Radiation induced dermatitis

\section{Pathophysiology and clinical presentation of Ra- diation dermatitis}

Mechanistically, low linear energy transfer (LET) energy sources (like X-ray, gamma irradiation) commonly used in treating cancer predominantly mediate their cytotoxic effects by indirect effects through generating surplus free radicals resulting from radiolysis of water. These free radicals subsequently cause damage to macromolecules like DNA, proteins and lipids. Exposure to ionizing radiation also stimulates transcriptional activation of a cascade of cytokines, like tumour necrosis factor alpha (TNF- $\alpha$ ) and Interleukin 1 (IL-1), to activate inflammatory response. Radiation also modulates communication between cells, changes the skin's endothelial cells, and triggers skin cell death, thereby affecting repopulation by damaging the proliferating stem cells present in basal layer of the dermis. Cumulatively, all of these events impair cutaneous integrity and culminate in skin damage as characterized by swelling, redness, pigmentation, fibrosis, and ulceration of the skin. Severity of the symptoms depends on intrinsic factors like age, general health, ethnic origin, hormonal status, genetic predisposition, basal skin conditions, co morbidities, preexisting connective tissue and/or autoimmune disorders, and skin phototype; while extrinsic factors like radiation dose, volume, and number of fractions of radiation, the presence or absence of radio sensitizing concurrent chemotherapy play a role. ${ }^{5}$

Even when the skin is not the primary target, it may be injured as an "innocent bystander" and develop profound alterations on functional, gross, and molecular levels. Inevitably, however, a small fraction of rapidly proliferating cells in the basal layer of the skin are injured or destroyed, precipitating a decrease in the population of differentiated epidermal keratinocytes; this can result in desquamation-i.e. the peeling and shedding of the epidermis, depending on the total dose of radiation delivered. Impairment of the skin barrier function carries the risks of wound formation, loss of immune function, and infection. Further, radiation can also damage the microvascular system, increasing the risk of tissue hypoxia and fibrosis, and activating an inflammatory cascade, leading to acute and chronic skin chang$\mathrm{es}^{6}$ 
Transient, mild erythema can occur within hours of RT, likely due to capillary dilation shortly after patient exposure to radiation. However, the more conventional, sustained hyperpigmentation or erythema associated with RT typically does not occur until 2 to 4 weeks into treatment. Hair follicles and sebaceous glands can be affected early in the course of RT, leading to dry skin and hair loss. As erythema develops, a sunburn-like reaction is seen, with associated edema, pruritus, tenderness, and a burning sensation. Dry desquamation, which manifests as pruritus and flaking of the skin, may occur 3 to 6 weeks into the RT regimen, at cumulative doses above $20 \mathrm{~Gy}$. With increasing radiation doses above 30 to $40 \mathrm{~Gy}$, patients may develop moist desquama- tion - a condition that is characterized by tender, red skin associated with serous exudate, haemorrhagic crusting, and the potential for development of bullae. Due to breakdown of the skin barrier, this stage is generally painful. It is characterized by increased susceptibility to contact injury, particularly in flexural areas prone to frictional stress; by infection; and by ulcer formation. In cases of extreme desquamation, physicians may need to withhold RT for a period of time, to allow for sufficient re-epithelialization before the patient resumes treatment.

The acute phase of radiation dermatitis is often defined as the changes seen within 90 days following RT. The development of acute radiation dermatitis follows a predictable course (Table 1).

Table 1: Clinical symptoms and time of onset of acute radiation dermatitis

\begin{tabular}{|c|c|c|}
\hline Skin reaction & Time of onset post RT & Radiation Dose at onset \\
\hline 1) Hyperpigmentation / erythema & $1-2$ weeks & 10-40 Gy \\
\hline 2) Dry desquamation & 3-4 weeks & 20-30Gy \\
\hline 3) Wet desquamation & $>4$ weeks & $30-40$ Gy \\
\hline
\end{tabular}

Radiation induced dermatitis is most often seen in patients receiving treatment for sarcoma and cancers of the skin, breast, head and neck, vulva, and anus, since the target area of treatment is often close to the skin, with limited ability to spare the skin from higher doses of radiation exposure (Table 3$)^{7}$

Table 3: Grades of radiation dermatitis most affected by this side effects

\begin{tabular}{|l|l|l|l|l|}
\hline RTOG/CTCAE & Breast cancer & Vulvar cancer & Head and neck cancer & Anal Cancer \\
\hline 0 & $6 \%$ & $0 \%$ & $1 \%$ & $76 \%$ \\
\hline 1 & $61 \%$ & $11 \%$ & $20 \%$ & $16 \%$ \\
\hline 2 & $24 \%$ & $67 \%$ & $57 \%$ & $5 \%$ \\
\hline 34 & $9 \%$ & $22 \%$ & $23 \%$ & $3 \%$ \\
\hline
\end{tabular}

While multiple systems exist for the grading of skin effects from RT, the ones most referenced are the Radiation Therapy Oncology Group grading scale and the National Cancer Institute Common Terminology Criteria for Adverse Events, version $4.03^{8}$

Table 2: Scoring system

\begin{tabular}{|l|l|l|l|l|l|l|}
\hline Scale & 0 & 1 & 2 & 3 & 4 \\
\hline RTOG & $\begin{array}{l}\text { No } \\
\text { change }\end{array}$ & $\begin{array}{l}\text { Faint erythema } \\
\text { Dry desquamation } \\
\text { Epilation } \\
\text { Decreased sweating }\end{array}$ & $\begin{array}{l}\text { Tender or bright ery- } \\
\text { thema } \\
\text { Moderate oedema } \\
\text { Patchy moist des- } \\
\text { quamation }\end{array}$ & $\begin{array}{l}\text { Moist desquamation } \\
\text { other than skin folds }\end{array}$ & Ulceration & Haemorrhage \\
\hline CTCAE & $\begin{array}{l}\text { No } \\
\text { change }\end{array}$ & $\begin{array}{l}\text { Faint erythema } \\
\text { Dry desquamation }\end{array}$ & $\begin{array}{l}\text { Moderate desquama- } \\
\text { tion } \\
\text { Moderate oedema } \\
\text { Patchy moist des- } \\
\text { quamation confined } \\
\text { to skin folds }\end{array}$ & $\begin{array}{l}\text { Moist desquamation } \\
\text { other than skin folds } \\
\text { minor trauma }\end{array}$ & $\begin{array}{l}\text { Life threatening conse- } \\
\text { quences- full thickness } \\
\text { necrosis, } \\
\text { spontaneous } \\
\text { ulceration, } \\
\text { bleeding }\end{array}$ \\
\hline
\end{tabular}


Chronic radiation dermatitis is typically defined as changes that occur more than 90 days following a course of RT. Chronic skin changes may result from aberrant or dysregulated alterations in proinflammatory and profibrotic cytokines. These changes may include hypopigmented and/or hyperpigmented skin that persists or develops after resolution of the acute phase of dermatitis. There may be sustained loss of certain skin structures such as sebaceous glands, hair follicles, and nails, as well as textural changes to the skin. Radiation-induced fibrosis is a potentially serious sequela of RT that may cause poor cosmesis, lymphedema, skin retraction, persistent hyperpigmentation, and joint immobility. ${ }^{9}$ Telangiectasia may occur as a result of blood vessel dilation, while damage to blood vessels may also result in tissue hypoxia, predisposing the patient to development of skin ulceration and/or chronic wounds. ${ }^{10}$ In summary, depending on the severity and location of chronic skin changes after RT, there is potential for decreased quality of life due to pain, recurrent wounds, decreased range of motion, and cosmetic dissatisfaction.

\section{Ayurvedic treatment modalities in Radiation in- duced dermatitis}

Ayurvedic Samprapti of Radiation induced dermatitis can be described as involvement of all three Doshas particularly vitiation of Pitta, affecting the Rasa, Rakta And Mansa Dhatu and out of the three Malas affecting the Sweda. The effects of the radiation can be compared to the DushiVishas. Premonitory symptoms of Dushivisha has many skin manifestations like Mandala, Kotha, Kushtha etc.

Ayurvedic treatment modalities in managing radiation induced dermatitis can be classified as Shaman Chikitsa And Sthanik Chikitsa. Recently, herbalbased drugs have also been used, and scientific reports indicate that Sandalwood oil and turmeric based cosmeceutical creams are beneficial. There are several articles regarding use of curcumin and its effect in radiation induced dermatitis. ${ }^{11}$ The antiinflammatory properties of curcumin are well known to Ayurveda for a long time and has been in use since then for various inflammatory disorders. Similar such drugs like Neem oil which also has similar anti-inflammatory properties have been studied in radiation induced dermatitis. ${ }^{12}$ Yashtimadhu is a very well-known immuno modulator $\&$ due to its
Twachya properties also gaining importance in overcoming the skin changes due to radiation. ${ }^{13}$ The radioprotective effect of Triphala was studied and found that Triphala being an immuno modulatory and anti-inflammatory drug has good potential in overcoming the skin related side effects. ${ }^{14}$ Studies carried out in the past 2 decades have shown that some of the classical Indian Ayurvedic drugs like Amritaprasham, Ashwagandha Rasayana, Brahma Rasayana, Chyavanprasha, Narasimha Rasayana, and Triphala Churna possess radioprotective effects.

As per Sushrut Samhita, the management of DushiVisha includes Shodhan followed by various Agad like Dushivishari Agad, Ajay Ghrita etc. But in cancer patients undergoing radiation therapy the $\mathrm{Bal}$ of patient is not good thus Shodhan Chikitsa can be avoided. But different Agad can be used in managing radiation induced dermatitis.

Various terms like Kusthaghna, Kustha Hara, Kusthanut, Kandughna Switrahara, Varnya etc. have been used in Nighantus to explain the specific action of drugs. Such drugs can also be used according to the symptoms.

In management of the radiation dermatitis, local treatments like application of Lepa ,Pichu, Dhavan with the help of various drugs like Yashti, Triphala, Hardira, Sariva, Manjistha etc which possess the anti-inflammatory properties can be used.${ }^{15}$ In Shaman Chikitsa, drugs which possess Rasayana properties can be used to avoid the late complications and also help to improve the quality of life of patient. Following Dincharya And Rutucharya are the best lifestyle modifications one can be benefited from.

\section{DISCUSSION}

Radiation dermatitis is one of the most common side effects of RT. Acute reactions may range from erythema and sale to moist desquamation with pain, weeping of serous fluid, and the formation of bullae. Chronic skin changes that may develop, and which can persist, include fibrosis, telangiectasias, and skin atrophy. While the acute side effects of irradiation typically resolve within 2 to 4 weeks of RT completion, the dermatologic reactions can be uncomfortable and even painful, carry the risk of infection, and may negatively impact a patient's quality of life. 
Despite the prevalence of radiation dermatitis, as previously noted, there is no gold standard in the prevention and management of this condition, and many interventions are based on provider experience, anecdotal evidence, or poorly powered studies. Modern day oncology care demands the multimodality approach in treating the cancer patients. Ayurveda has the potential in treating such side effects caused due to the conventional treatment modalities. The goals of treatment are largely geared toward improving patient comfort, minimizing risk of further injury, and enhancing wound healing. Rigorous, well-designed studies are needed as we move forward to optimize the prevention and management of radiation dermatitis with the help of Ayurveda.

\section{CONCLUSION}

Multi-modality approach in cancer management, poorly affected quality of life, dose limiting toxicity are some challenges for modern medicine. Ayurvedic medicines have a lot of scope and usefulness in overcoming these challenges. The antiinflammatory, antioxidant and Rasayana properties of various drugs have the potential in preventing and treating acute and chronic radiation induced dermatitis. Such medicinal herbs can be used in the form of internal medicines or in the form of local treatments. Thus, there is a lot of scope for Ayurveda in managing acute and chronic radiation induced dermatitis.

\section{REFERENCES}

1. https://cebp.aacrjournals.org/content/cebp/early/2017 /05/03/1055-9965.EPI-16-1023.full.pdf

2. https://www.ncbi.nlm.nih.gov/pubmed/27021652

3. https://www.jaad.org/article/S0190-9622(05)027076/fulltext

4. Sushruta Samhita, Acharya Yadavji Trikamji editor. Varanasi: Chaukhamba Surbharati. Kalpasthana, $3 / 33$.

5. https://www.mdpi.com/2305-6320/4/3/43/htm\#B10medicines-04-00043

6. Zeman E. The biological basis of radiation oncology. In: Gunderson LL, Tepper JE, Bogart JA, editors. Clinical radiation oncology. 4th ed. Philadelphia, PA: Elsevier; 20
7. https://www.cancernetwork.com/oncologyjournal/radiation-dermatitis-recognition-preventionand-management

8. Cox JD, Stetz J, Pajak TF. Toxicity criteria of the Radiation Therapy Oncology Group (RTOG) and the European Organization for Research and Treatment of Cancer (EORTC). Int J Radiat Oncol Biol Phys. 1995; 31:1341-6

9. Hymes SR, Strom EA, Fife C. Radiation dermatitis: clinical presentation, pathophysiology, and treatment 2006. J Am Acad Dermatol. 2006; 54:28-46

10. Spalek M. Chronic radiation-induced dermatitis: challenges and solutions. Clin Cosmet Investig Dermatol. 2016; 9:473-82.

11. https://www.ncbi.nlm.nih.gov/pmc/articles/PMC399 $8827 /$

12. https://rojournal.biomedcentral.com/articles/10.1186/ s13014-014-0297-0

13. https://www.ncbi.nlm.nih.gov/pmc/articles/PMC329 $6340 /$

14. https://www.sciencedirect.com/science/article/abs/pii /S0944711304700884

15. https://pubmed.ncbi.nlm.nih.gov/23737641rasayana-drugs-from-the-ayurvedic-system-ofmedicine-as-possible-radioprotective-agents-incancer-treatment/

\section{Source of Support: Nil Conflict of Interest: None Declared}

How to cite this URL: Sonawane Vrushali \& Narode Sagar: Potential Of Ayurvedic Treatment Modalities In Radiation Induced Dermatitis. International Ayurvedic Medical Journal \{online\} 2020 \{cited July, 2020\} Available from: http://www.iamj.in/posts/images/upload/3959_3963.pdf 